\title{
KARAKTERISTIK DAN SIFAT KINETIKA ENZIM KITINASE DARI ISOLAT BAKTERI T5a1 ASAL TERASI
}

\author{
Dedi Noviendri*), Yusro Nuri Fawzya*), dan Ekowati Chasanah")
}

\begin{abstract}
ABSTRAK
Karakterisasi dan studi kinetika enzim kitinase dari isolat T5a1 asal terasi telah dilakukan. Karakterisasi ini mencakup penentuan suhu dan $\mathrm{pH}$ optimum, kestabilan enzim pada suhu optimumnya, dan pengaruh adanya ion logam terhadap aktivitas enzim. Dari hasil penelitian ini diketahui bahwa enzim kitinase T5a1 mempunyai suhu dan $\mathrm{pH}$ optimum masing-masing adalah $40^{\circ} \mathrm{C}$ dan 6,0 . Enzim ini masih tetap stabil sampai dengan 160 menit inkubasi pada suhu $40^{\circ} \mathrm{C}$. Kation $\mathrm{Fe}^{3+}$ dan $\mathrm{Ca}^{2+}$ dapat meningkatkan aktivitas enzim kitinase, sedangkan kation monovalin $\mathrm{Mn}^{2+}, \mathrm{Mg}^{2+}, \mathrm{Cu}^{2+}, \mathrm{Co}^{2+}, \mathrm{Zn}^{2+}, \mathrm{Ba}^{2+} \mathrm{NH}_{4}^{+}, \mathrm{K}^{+}$, dan $\mathrm{Na}^{+}$dengan konsentrasi akhir 1,0 mM dapat menurunkan aktvitas enzim kitinase dari isolat T5a1. Nilai $\mathrm{V}_{\text {maks }}$ dan $\mathrm{K}_{\mathrm{m}}$ enzim kitinase T5a1 ini masing-masing adalah sebesar $0,0048 \mathrm{U} / \mathrm{mL}$ dan $1,037 \mathrm{mg} / \mathrm{mL}$.
\end{abstract}

\section{ABSTRACT: Characteristics and kinetics of chitinase enzyme produced by T5a1 isolated} from terasi. By: Dedi Noviendri, Yusro Nuri Fawzya and Ekowati Chasanah

Characteristics and kinetics of chitinase enzyme produced from T5a 1 isolated from fish paste have been studied. This characterization included assessment of optimal temperature and $\mathrm{pH}$, enzyme stability and metal ion influence toward enzyme activity. The result of experiment showed that the optimal temperature and $\mathrm{pH}$ of the enzyme activity were $40^{\circ} \mathrm{C}$ and 6.0 , respectively. At 40 ${ }^{\circ} \mathrm{C}$ this enzyme was still stable until 160 minutes. It was found that the $\mathrm{Fe}^{3+}$ and $\mathrm{Ca}^{2+}$ increased the enzyme activity, whereas $1 \mathrm{mM} \mathrm{Mn}^{2+}, \mathrm{Mg}^{2+}, \mathrm{Cu}^{2+}, \mathrm{Co}^{2+}, \mathrm{Zn}^{2+}, \mathrm{Ba}^{2+}, \mathrm{NH}_{4}^{+}, \mathrm{K}^{+}$and $\mathrm{Na}^{+}$decreased the activity. $V_{\max }$ and $K_{m}$ values of the enzyme were observed on $0.0048 \mathrm{U} / \mathrm{mL}$ and $1.037 \mathrm{mg} / \mathrm{mL}$, respectively.

\section{KEYWORDS: chitinase enzyme, T5a1 terasi's bacterial isolate, characteristics and kinetics}

\section{PENDAHULUAN}

Kitin merupakan senyawa homopolimer polisakarida alami rantai panjang berbentuk linier (Tokuyasu et al., 1999) yang mempunyai kelimpahan sangat besar dalam biosfer (Gohel et al., 2006). Polimer ini tersusun dari residu $\mathrm{N}$-asetilglukosamin (GlcNac) (Park et al., 2000; Dahiya et al., 2005a) yang dihubungkan oleh ikatan $\beta-(1,4)$-glikosidik (Wang \& Chang, 1997; Oh et al., 2000; Purwani, 2002), tidak bercabang, mempunyai bobot molekul besar dan jumlahnya sangat berlimpah di alam. Kitin merupakan komponen utama dari kulit udang atau golongan krustase (Mahadevan \& Crawford, 1997), eksoskeleton dari zooplankton laut seperti coral dan ubur-ubur (Gohel et al., 2006), kulit insekta dan bahkan juga terkandung dalam beberapa jenis kapang (fungi). Senyawa kitin ini merupakan biopolimer (Tanaka et al., 1999) terbesar kedua setelah selulosa (Martinou et al., 1995; Thatte, 2004). Enzim kitinase (E.C.3.2.1.14) termasuk kelompok enzim hidrolase yang dapat mendegradasi kitin secara langsung menjadi produk dengan berat molekul kecil, yang banyak dihasilkan oleh mikroorganisme (Wang \&
Chang, 1997), baik secara intra maupun ekstraseluler. Enzim ini dapat mendegradasi kitin polimerik menjadi oligosakarida kitin, deasetilkitobiosa, dan Nasetilglukosamin (Thompson et al., 2001). Kebutuhan nutrisi mikroorganisme pendegradasi kitin dipenuhi oleh kitinase ekstraseluler yang mendegradasi bahanbahan berkitin.

Mikroorganisme prokariot pendegradasi kitin (memiliki enzim kitinase) umumnya berasal dari kelompok bakteri peluncur (gliding bacteria), Pseudomonas, Vibrio, Photobacterium, Actinomycetes, Bacillus, Aeromonas, Streptomyces, dan Clostridium. Di antara bakteri tersebut diketahui bahwa Pseudomonas, Bacillus, dan Streptomyces ditemukan pada lingkungan alkali. Selain itu kitinase juga dihasilkan oleh mikroorganisme eukariotik seperti Myxomycetes, Zygomycetes, Deuteromycetes, Ascomycetes, dan Basidiomycetes (Gooday, 1990 dalam Situmorang, 2003). Isolasi bakteri kitinolitik dari hasil perikanan dan produk olahannya telah dilakukan (Zilda \& Chasanah, 2005; Uria \& Chasanah, 2005). Beberapa isolat bakteri kitinolitik potensial yang telah diisolasi adalah JB4 (Staphylococcus captis) (Noviendri et al., 2006; Noviendri \& Fawzya, 2008)

") Peneliti pada Balai Besar Riset Pengolahan Produk dan Bioteknologi Kelautan dan Perikanan, DKP 
dan T5a1 dari terasi, 34bs dari sponge dan KPU218 dari limbah udang (Krisnawang et al., 2006). Dari beberapa isolat bakteri kitinolitik yang telah berhasil diisolasi, isolat T5a1 merupakan bakteri yang terpilih untuk diteliti lebih lanjut untuk produksi enzim kitinase. Penelitian ini bertujuan untuk mengetahui karakter dan kinetika enzim kitinase dari isolat T5a1 guna memudahkan aplikasi selanjutnya.

\section{BAHAN DAN METODE}

\section{Produksi Enzim}

Isolat T5a1 murni hasil isolasi dari terasi (Zilda \& Chasanah, 2005) ditumbuhkan dalam media Minimally Syntetic Medium (MSM) ) padat steril (Katatny et al., 2000), kemudian sebanyak dua ose isolat dikultivasi ke dalam $25 \mathrm{~mL}$ medium MSM cair dan diinkubasi pada suhu $37^{\circ} \mathrm{C}$ selama 24 jam pada waterbath shaker dengan kecepatan $120 \mathrm{rpm}$, dan siap dijadikan starter. Starter dengan konsentrasi 10\% (v/v) ditumbuhkan di dalam medium cair pada suhu $37^{\circ} \mathrm{C}$ selama satu malam pada waterbath shaker. Pada akhir masa fermentasi, biomassa dipisahkan dengan cara sentrifugasi dengan kecepatan $8.000 \mathrm{~g}$ pada suhu $4^{\circ} \mathrm{C}$ selama 15 menit untuk diambil supernatannya. Enzim dikonsentrasikan dengan teknik salting out, yaitu dengan menambahkan amonium sulfat ke dalam supernatan hingga mencapai $40 \%$ tingkat kejenuhan (\%TK) (Uria \& Chasanah, 2005; Zilda \& Chasanah, 2005). Endapan dikumpulkan dengan cara sentrifugasi dengan kecepatan 8.000 g pada suhu $4^{\circ} \mathrm{C}$ selama 15 menit. Endapan (enzim) ini kemudian dilarutkan dalam $15 \mathrm{~mL}$ bufer fosfat $0,05 \mathrm{M} \mathrm{pH} \mathrm{7,0;} \mathrm{Ialu} \mathrm{didialisis} \mathrm{di}$ dalam bufer yang sama pada suhu $4^{\circ} \mathrm{C}$ selama semalam. Larutan enzim siap untuk digunakan pada pengujian selanjutnya.

\section{Pengujian Aktivitas Enzim}

Aktivitas enzim kitinase diuji berdasarkan metode Splinder (1997) yang dimodifikasi. Modifikasi ini dilakukan pada nilai konsentrasi dan volume pereaksi yang digunakan berdasarkan penelitian pendahuluan. Pengujian aktivitas enzim dilakukan dengan menggunakan substrat koloidal kitin dengan konsentrasi $1,5 \%(b / v)$. Larutan enzim $(150 \mu \mathrm{L})$ ditambahkan ke dalam campuran yang mengandung $300 \mu \mathrm{L}$ koloidal kitin 1,5\% dan $150 \mu \mathrm{L}$ bufer fosfat dengan $\mathrm{pH} 7,0$. Campuran diinkubasi pada suhu $37^{\circ} \mathrm{C}$ selama 10 menit. Selanjutnya disentrifugasi pada kecepatan $9.000 \mathrm{~g}$ pada suhu $4^{\circ} \mathrm{C}$ selama 5 menit. Pelet dibuang dan supernatan diambil sebanyak 200 $\mu \mathrm{L}$, lalu ditambah dengan $500 \mu \mathrm{L} \mathrm{H}_{2} \mathrm{O}$ dan $1.000 \mu \mathrm{L}$ pereaksi Schales, selanjutnya dididihkan selama 10 menit. Setelah dingin, absorbansi larutan diukur pada panjang gelombang $420 \mathrm{~nm}$ dengan menggunakan spektrofotometer UV-VIS (UV-1201 Shimadzu). Satu unit aktivitas kitinase didefiniskan sebagai jumlah enzim yang menghasilkan $1 \mu \mathrm{mol}$ gula reduksi yang ekivalen dengan $\mathrm{N}$ - asetilglukosamin ( $G / c N A c)$ selama 1 menit.

\section{Karakterisasi Enzim Kitinase}

Karakterisasi enzim yang dilakukan adalah, penentuan suhu dan $\mathrm{pH}$ optimum enzim, penentuan stabilitas enzim pada suhu opimalnya dan pengaruh kation terhadap aktivitas enzim.

\section{Pengaruh Suhu dan pH terhadap Aktivitas Enzim}

Aktivitas enzim diukur pada berbagai suhu untuk menentukan suhu optimumnya. Suhu yang digunakan adalah $30,37,40,50,60$, dan $70^{\circ} \mathrm{C}$. Sedangkan $\mathrm{pH}$ optimum ditentukan dengan cara mereaksikan enzim kitinase dengan substrat pada berbagai $\mathrm{pH}$, kemudian mengukur aktivitasnya pada suhu optimumnya. Bufer yang digunakan meliputi bufer sitrat $(\mathrm{pH} 4,0-6,0)$, bufer

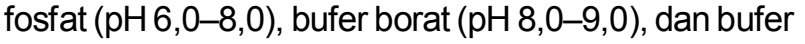
glisin ( $\mathrm{pH} 9,0-10,0)$. Konsentrasi bufer yang digunakan pada penelitian ini adalah 0,2 M.

\section{Penentuan Stabilitas Enzim pada Suhu Optimumnya}

Penentuan stabilitas enzim dilakukan dengan cara inkubasi larutan enzim $(50 \mu \mathrm{L})$ dalam waterbath pada suhu optimumnya selama $0,15,30,45,60,80,100$, 120 , dan 160 menit, lalu didinginkan dengan es selama 15 menit, kemudian diuji aktivitasnya.

\section{Pengaruh Kation Terhadap Aktivitas Enzim}

Pengaruh penambahan kation terhadap aktivitas enzim kitinase diuji dengan menggunakan kation monovalen $\left(\mathrm{NH}_{4}^{+}, \mathrm{K}^{+}\right.$, dan $\left.\mathrm{Na}^{+}\right)$, divalen $\left(\mathrm{Ca}^{2+}, \mathrm{Mn}^{2+}\right.$, $\mathrm{Li}^{2+}, \mathrm{Co}^{2+}, \mathrm{Zn}^{2+}, \mathrm{Ba}^{2+}$, dan $\left.\mathrm{Mg}^{2+}\right)$, dan trivalen $\left(\mathrm{Fe}^{3+}\right)$ dalam bentuk garam kloridanya. Senyawa ini ditambahkan ke dalam enzim dengan konsentrasi akhir 1,0 mM (Wang \& Chang, 1997; Rahayu et al., 2004). Campuran ini diikubasi selama 15 menit pada suhu $40^{\circ} \mathrm{C}$ (suhu optimum enzim untuk kedua isolat), kemudian diukur aktivitasnya. Sebagai kontrol dalam pengujian ini dipergunakan larutan enzim yang tidak mengandung logam yang diujikan.

\section{Kinetika Enzim}

Parameter yang diamati dalam kinetika enzim ini adalah nilai kecepatan maksimum $\left(\mathrm{V}_{\text {maks }}\right)$, dan konstanta Michaelis-Menten $\left(\mathrm{K}_{\mathrm{m}}\right)$ dari enzim kitinase. Nilai $K_{m}$ yang diukur menunjukkan besarnya 
konsentrasi substrat yang dicapai pada kecepatan $1 / 2$ $\mathrm{V}_{\text {maks }}$. Dalam penentuan kinetika enzim ini, digunakan substrat koloidal kitin dengan konsentrasi 0 sampai dengan $7,5 \mathrm{mg} / \mathrm{mL}$.

\section{HASIL DAN BAHASAN}

\section{Pengaruh Suhu Terhadap Aktivitas Enzim}

Pengaruh suhu terhadap aktivitas kitinase dari penelitian ini dapat dilihat pada Gambar 1. Aktivitas maksimum kitinase dari isolat $\mathrm{T} 5 \mathrm{a} 1$ dicapai pada suhu $40^{\circ} \mathrm{C}$ sebesar $1,759 \mathrm{U} / \mathrm{mL}$, tetapi mengalami penurunan pada suhu $50^{\circ} \mathrm{C}$. Wang \& Chang (1997) menemukan bahwa dua kitinase yang dihasilkan oleh Pseudomonas aeruginosa K-187 mempunyai suhu optimum 40 dan $50^{\circ} \mathrm{C}$. Suhu optimum sebesar $45^{\circ} \mathrm{C}$ dimiliki oleh kitinase dari Vibrio sp. 98CJ1102 (Park et al., 2000), Enterobacter sp. NRG4 (Dahiya et al., 2005b), dan Arthrobacter sp. NHB-10 (Okazaki et al., 1996). Enzim kitinase yang berasal dari isolat T5a1 ini dapat digolongkan ke dalam enzim kitinase mesofilik yang mempunyai suhu optimum berkisar antara $25-45^{\circ} \mathrm{C}$.

Pada umumnya peningkatan suhu inkubasi dapat menyebabkan peningkatan aktivitas enzim karena peningkatan kecepatan gerak termal molekul, sehingga meningkatkan jumlah molekul yang mempunyai energi cukup untuk memasuki keadaan transisinya. Kenaikan suhu $10^{\circ} \mathrm{C}$ biasanya mengakibatkan kenaikan aktivitas enzim sebanyak dua kali lipat (Bollag \& Edelstein, 1991). Aktivitas tertinggi enzim akan diperoleh pada suhu optimumnya (Jayanti, 2002).

\section{Pengaruh pH Terhadap Aktivitas Enzim}

Enzim memiliki pH optimum yang khas, yaitu $\mathrm{pH}$ yang menyebabkan aktivitas maksimum (Lehninger, 1995). Semua reaksi enzim dipengaruhi oleh $\mathrm{pH}$ medium tempat reaksi terjadi (Suhartono, 1989), dan pada umumnya enzim aktif pada $\mathrm{pH}$ netral atau dengan kisaran pH 5-9 (Suhartono, 1989; Rahayu, 2000). Pengaruh $\mathrm{pH}$ terhadap aktivitas enzim dapat dilihat pada Gambar 2. Aktivitas maksimum isolat T5a1 dicapai pada pH 6,0 bufer fosfat sebesar 0,696 $\mathrm{U} / \mathrm{mL}$. Hal ini mirip dengan hasil penelitian Okazaki pada tahun 1995 dengan menggunakan Streptomyces sp J-13-3, bahwa $\mathrm{pH}$ optimum dua kitinase yang dihasilkan oleh mikroorganisme tersebut adalah 6,0 (Rahayu, 2000).

Nilai pH optimum 6,0 juga ditemukan pada kitinase Trichoderma harzianum (Katatny et al., 2000), Bacillus licheniformis MB-2 (Situmorang, 2003), Vibrio sp. 98CJ1102 (Park et al., 2000) dan isolat 13,30 yang diisolasi dari Manado (Jayanti, 2002). Sedangkan kitinase yang memiliki $\mathrm{pH}$ optimum 7,0 ditemukan pada isolat 13,5 (Jayanti, 2002), isolat K-29-14 yang diisolasi dari kawah Kamojang Jawa Barat (Rahayu, 2000; Rahayu et al., 2004), dan isolat bakteri termofilik GP18 yang diisolasi dari sumber air panas Gunung Pancar (Lestari, 2000), pH optimum 8,0 pada isolat 12,2 (Jayanti, 2002), pH optimum 7,0-8,0 pada isolat 13,9 (Jayanti, 2002) dan Bacillus sp. 13,26 (Purwani et al., 2004). Sedangkan dua kitinase yang dihasilkan oleh Pseudomonas aeruginosa K-187 mempunyai $\mathrm{pH}$ optimum 7,0 dan 8,0 (Wang \& Chang, 1997).

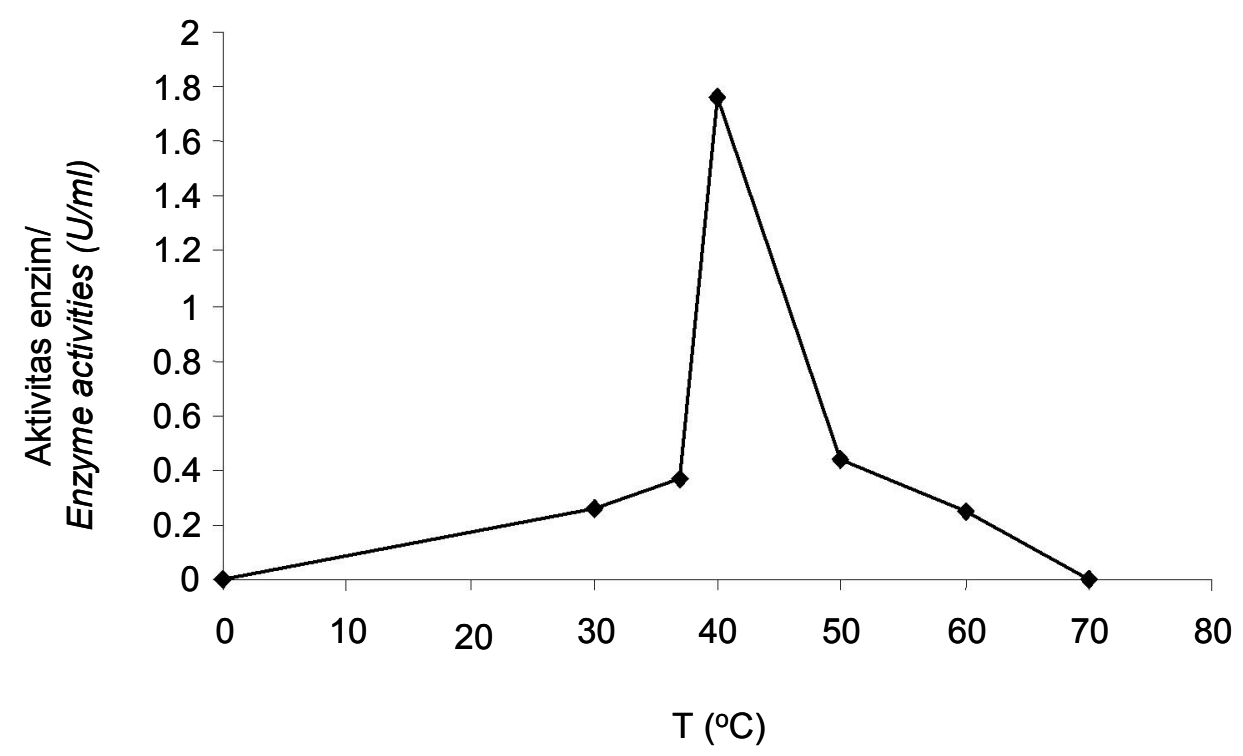

Gambar 1. Pengaruh suhu terhadap aktivitas kitinase dari isolat T5a1.

Figure 1. The effect of temperature on chitinase activity of T5a1 isolate. 


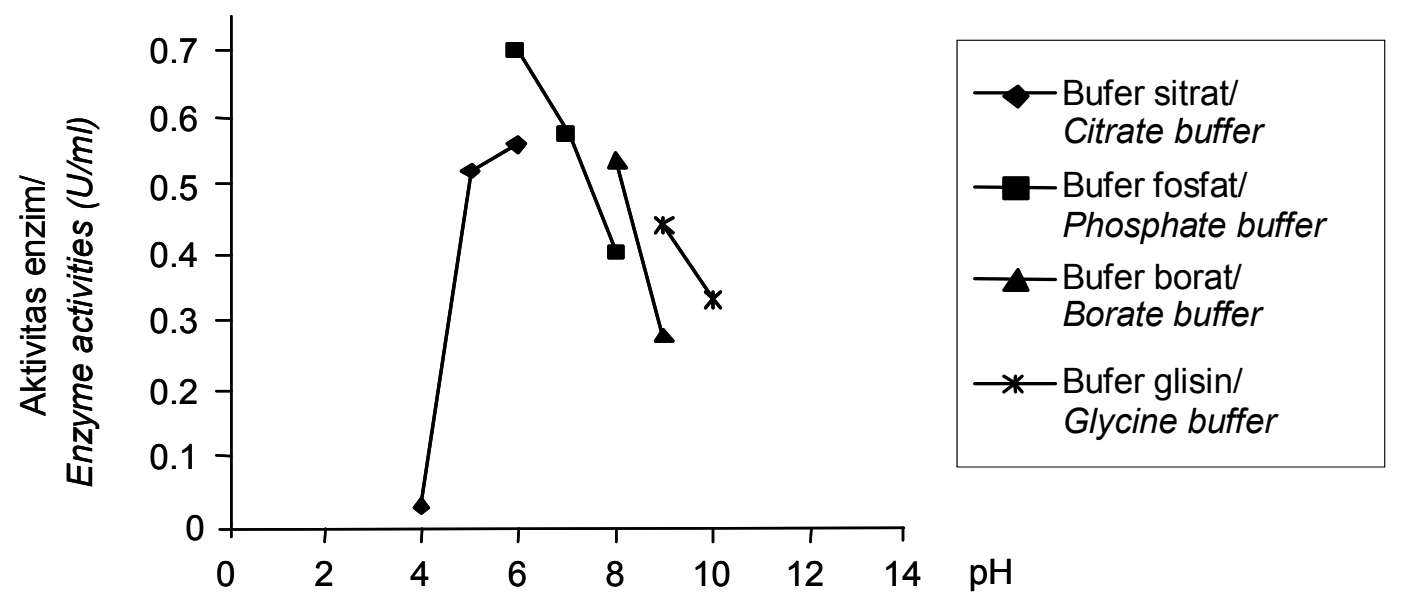

Gambar 2. Pengaruh $\mathrm{pH}$ terhadap aktivitas kitinase dari isolat T5a1.

Figure 2. The effect of $\mathrm{pH}$ on the activity of chitinase produced from T5a1 isolate.

\section{Pengujian Stabilitas Enzim pada Suhu Optimumnya}

Hasil pengujian stabilitas kitinase isolat T5a1 (Gambar 3) memperlihatkan profil kurva kestabilan terhadap panas yang relatif mirip dengan profil kurva kestabilan terhadap panas dari kitinase isolat JB4 (Noviendri et al., 2006). Aktivitas enzim kitinase dari isolat T5a1 pada inkubasi awal sebesar $0,938 \mathrm{U} / \mathrm{mL}$ mengalami kenaikan sampai sebesar $0,938 \mathrm{U} / \mathrm{mL}$ pada waktu inkubasi 80 menit, setelah itu mengalami penurunan secara perlahan menjadi $0,951 \mathrm{U} / \mathrm{mL}$ seiring dengan pertambahan waktu inkubasi 160 menit inkubasi. Hal ini menunjukkan bahwa enzim kitinase mengalami kerusakan/denaturasi yang semakin meningkat dengan bertambahnya waktu inkubasi.
Stabilitas enzim merupakan fungsi dari kekuatankekuatan penstabil enzim yaitu, ikatan hidrogen, ikatan hidrofobik, interaksi ionik, ikatan logam, dan jembatan disulfida (Suhartono, 1989). Semakin tinggi kekuatan penstabil enzim, maka enzim akan semakin stabil (Rahayu, 2000). Enzim kitinase yang berasal dari Bacillus sp. 13,26 dapat stabil sampai waktu 5 jam pada suhu $60-80^{\circ} \mathrm{C}$ (Purwani et al., 2004), dan dari Bacillus K-29-14 dapat stabil sampai waktu 5 jam pada suhu $70^{\circ} \mathrm{C}$ (Rahayu et al., 2004).

\section{Pengaruh Kation Terhadap Aktivitas Enzim}

Beberapa enzim diketahui membutuhkan ion-ion tertentu untuk menjamin aktivitasnya. Ion-ion tersebut dapat berperan sebagai aktivator pada konsentrasi

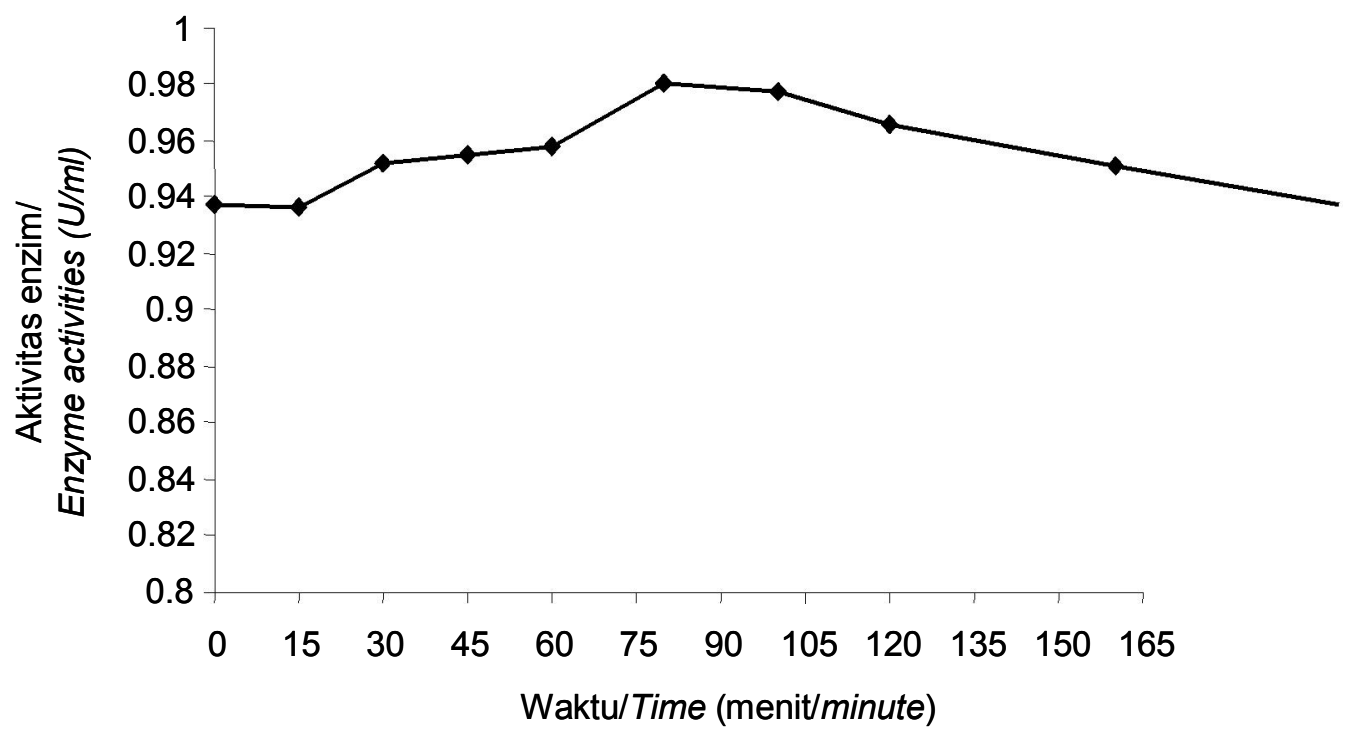

Gambar 3. Pengaruh lama inkubasi terhadap aktivitas kitinase dari isolat $T 5 a 1$ pada suhu $40^{\circ} \mathrm{C}$.

Figure 3. The effect of incubation time at $40^{\circ} \mathrm{C}$ on the activities of chitinase produced from T5a 1 isolate. 
tertentu atau sebagai inhibitor pada kondisi yang berbeda. Ion-ion logam ini diperlukan sebagai komponen pada sisi aktifnya. Pengaruh ion logam terhadap aktivitas relatif kitinase isolat T5a1 dapat dilihat pada Gambar 4.

Penambahan 1,0 mM kation $\mathrm{Mn}^{2+}, \mathrm{Mg}^{2+}, \mathrm{Cu}^{2+}$, $\mathrm{Co}^{2+}, \mathrm{Zn}^{2+}, \mathrm{Ba}^{2+}, \mathrm{NH}_{4}^{+}, \mathrm{K}^{+}$, dan $\mathrm{Na}^{+}$dapat menurunkan aktivitas enzim kitinase dari isolat T5a1. Kation $\mathrm{Mn}^{2+}$, $\mathrm{Mg}^{2+}$ dan $\mathrm{Zn}^{2+}$ dapat menurunkan aktivitas kitinase dari Pseudomonas aeruginosa K-187 (Wang \& Chang, 1997), kation $\mathrm{Cu}^{2+}, \mathrm{Co}^{2+}, \mathrm{Ag}^{+}$, dan $\mathrm{Hg}^{+}$pada kitinase dari Enterobactersp. NRG4 (Dahiya et al., 2005b), $\mathrm{Fe}^{2+}$ dan $\mathrm{Cu}^{2+}$ pada kitinase dari Vibrio sp. 98CJ11027 (Park et al., 2000) dan $\mathrm{Zn}^{2+}$ pada kitinase dari Bacillus K-129-14 (Rahayu et al., 2004). Dari semua kation yang dapat menurunkan aktivitas enzim kitinase dari isolate $\mathrm{T} 5 \mathrm{a} 1$, kation divalen $\mathrm{Co}^{2+}$ memiliki kemampuan tertinggi, sampai tinggal $54,07 \%$. Untuk enzim kitinase dari isolat T5a1 ini, penambahan 1,0 $\mathrm{mM}$ kation $\mathrm{Ca}^{2}$ dan $\mathrm{Fe}^{3+}$ dapat meningkatkan aktivitas enzim kitinase masing-masing menjadi $120,32 \%$ dan $131,71 \%$. Secara kimiawi, suatu inhibitor tidak dapat dibedakan dari aktivator. Setelah mereka berinteraksi dengan enzim, barulah dapat dilihat perbedaannya. Aktivator akan berikatan dengan enzim dan menyebabkan kenaikan kecepatan reaksi enzim, sedangkan inhibitor berikatan dengan enzim dan menyebabkan penurunan kecepatan reaksi enzim (Suhartono, 1989).

\section{Kinetika Enzim}

Salah satu faktor yang dapat mempengaruhi aktivitas enzim adalah konsentrasi substrat yang digunakan. Semakin tinggi konsentrasi substrat yang digunakan, maka semakin tinggi aktivitas enzim atau semakin tinggi kecepatan reaksi yang dikatalisis oleh enzim tersebut. Namun pada suatu titik tertentu, yaitu kecepatan maksimum $\left(\mathrm{V}_{\text {maks }}\right)$, adanya penambahan konsentrasi substrat dalam jumlah tertentu tidak akan dapat meningkatkan kecepatan reaksi enzim. Jika terus dilakukan penambahan konsentrasi substrat ke dalam reaksi yang dikatalisis oleh enzim, maka akan dapat menurunkan aktivitas enzim atau kecepatan reaksi. Dalam hal ini, substrat yang ditambahkan tersebut akan menjadi inhibitor dalam reaksi enzimatik. Dari hasil penelitian ini diperoleh nilai $\mathrm{V}_{\text {maks }}$ dan $\mathrm{K}_{\mathrm{m}}$ enzim kitinase dari isolat T5a1 adalah sebesar $0,0048 \mathrm{U} / \mathrm{mL}$ dan $1,037 \mathrm{mg} / \mathrm{mL}$ (Gambar 5). Bila dibandingkan dengan enzim kitinase 34bs (Erwinia sp.) (Noviendri \& Uria, 2008), maka nilai $V_{\text {maks }}$ dari enzim kitinase ini relatif lebih kecil, yaitu sebesar $0,2346 \mathrm{U} / \mathrm{ml}$. Sedangkan nilai $\mathrm{K}_{\mathrm{m}}$ nya relatif sama yaitu sebesar $1,61 \mathrm{mg} / \mathrm{mL}$.

\section{KESIMPULAN}

Enzim kitinase yang dihasilkan oleh isolat bakteri T5a1 dari terasi mempunyai suhu dan $\mathrm{pH}$ optimum $40^{\circ} \mathrm{C}$ dan 6,0 bufer fosfat. Enzim ini memiliki ketahanan terhadap panas yang relatif lama pada suhu $40^{\circ} \mathrm{C}$ yaitu 160 menit waktu inkubasi. Kation $\mathrm{Mn}^{2+}, \mathrm{Mg}^{2+}, \mathrm{Cu}^{2+}, \mathrm{Co}^{2+}, \mathrm{Zn}^{2+}, \mathrm{Ba}^{2+}, \mathrm{NH}_{4}^{+}, \mathrm{K}^{+}$, dan $\mathrm{Na}^{+}$ dengan konsentrasi 1,0 $\mathrm{mM}$ dapat menurunkan aktivitas enzim kitinase isolat T5a1. Sedangkan penambahan kation $\mathrm{Fe}^{3+}$ dan $\mathrm{Ca}^{2+}$ dapat meningkatkan aktivitas enzim kitinase. Nilai $\mathrm{V}_{\text {maks }}$ dan

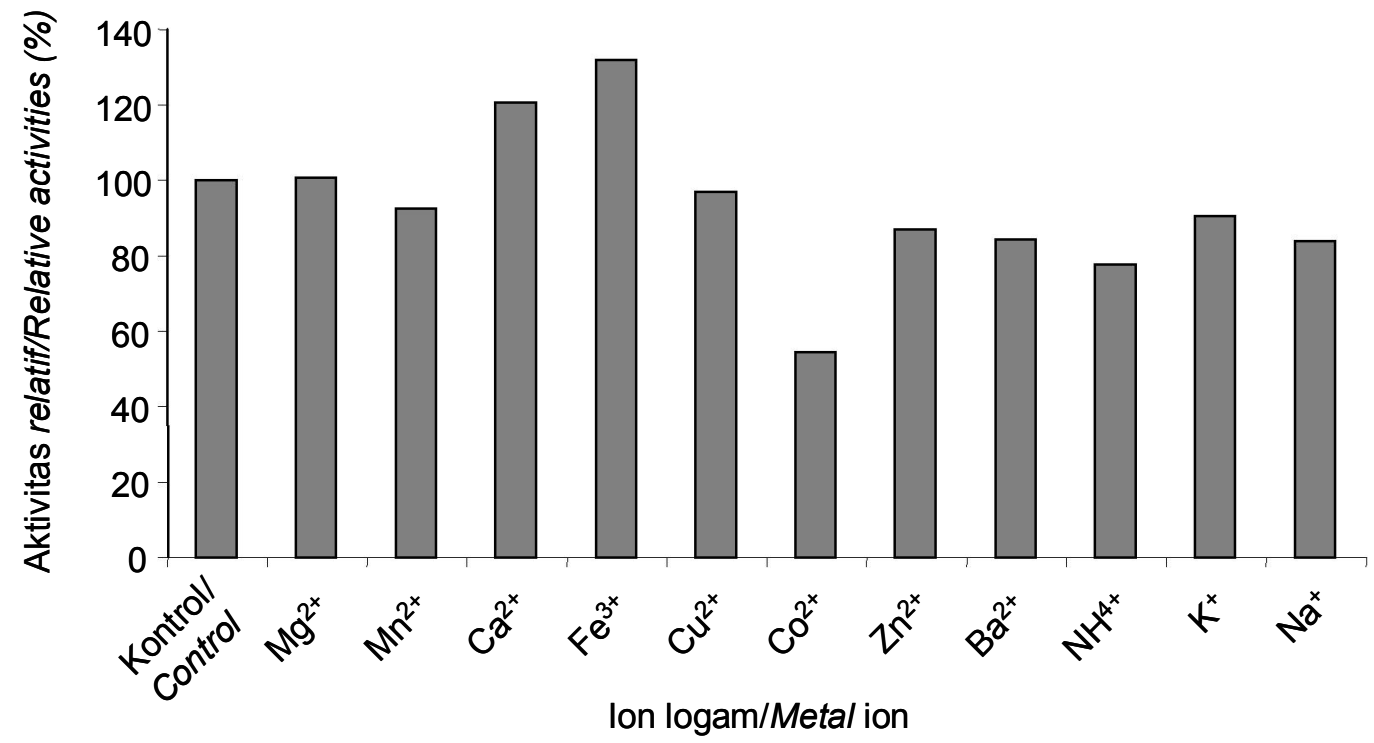

Gambar 4. Pengaruh ion logam terhadap aktivitas kitinase dari isolat T5a1 pada suhu $40^{\circ} \mathrm{C}$ dan $\mathrm{pH} 6,0$. Figure 4. Effect of metal ion on the activity of chitinase produced from T5a1 isolate measured at $40^{\circ} \mathrm{C}$ and $\mathrm{pH} 6.0$. 


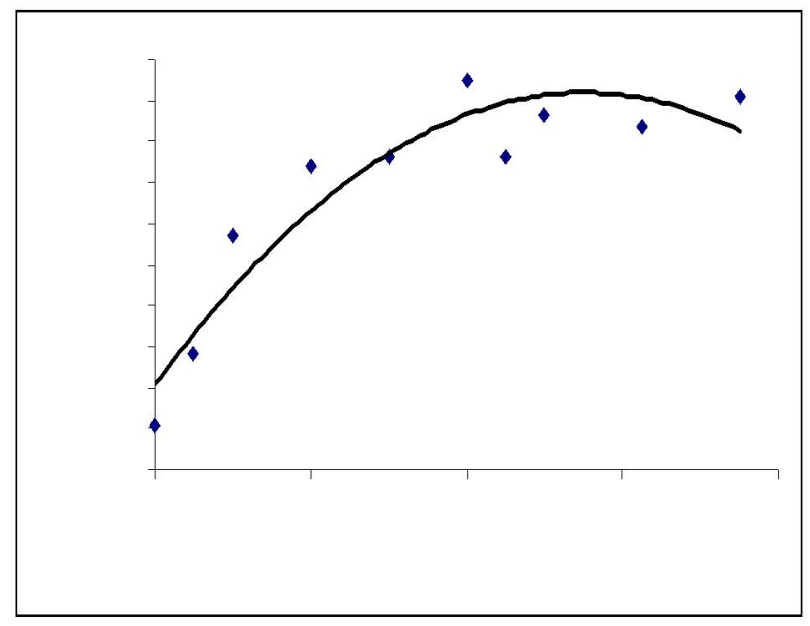

(A)

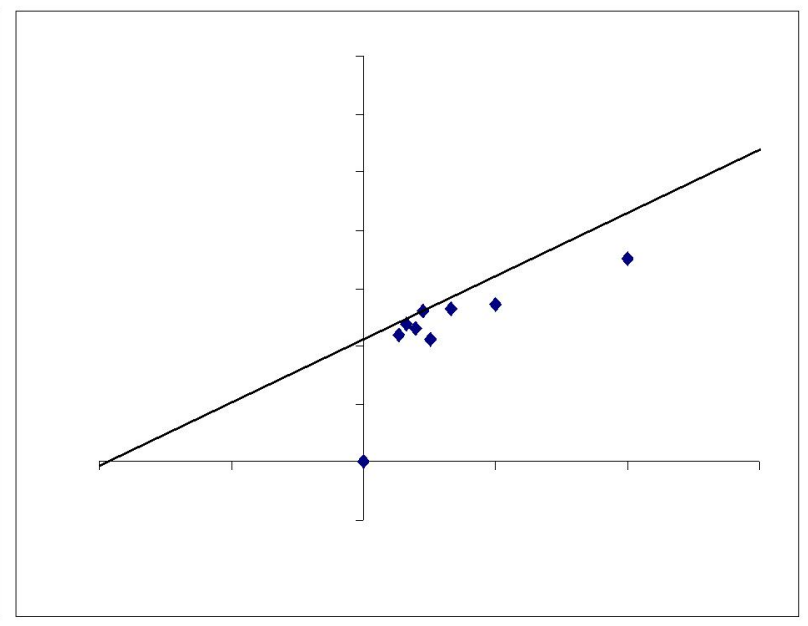

(B)

Gambar 5. Kurva Michaelis-Menten (A) dan Line WeaverBurk (B) enzim kitinase dari isolat T5a1. Figure 5. Michaelis-Menten (A) and Line WeaverBurk (B) curves of chitinase enzyme produced from T5a1 isolate.

$\mathrm{K}_{\mathrm{m}}$ kitinase dari isolat $\mathrm{T} 5 \mathrm{a} 1$ adalah masing-masing sebesar $0,0048 \mathrm{U} / \mathrm{ml}$ dan $1,037 \mathrm{mg} / \mathrm{ml}$.

\section{DAFTAR PUSTAKA}

Bollag, D.M. and Edelstein, S.J. 1991. Protein Methods. Willey-Liss, USA. 230 pp.

Dahiya, N., Tewari, R., and Hoondal, G.S. 2005a . Biotechnological aspects of chitinoliytic enzymes: a review. J. Appl. Microbiol Biotechnol. 71(6): 773-782

Dahiya, N., Tewari, R., Tiwari, R.P., and Hoondal, G.S. 2005 ${ }^{\text {b }}$ Chitinase from Enterobacter sp. NRG4: Its purification, Characterization and Reaction pattern. Elect. J. Biotechnol. 8(2):134-145.

Gohel, V., Singh, A., Vimal, M., Ashwini, P., and Chhatpar, H. S. 2006. Bioprospecting and antifungal potential of chitinolytic microorganism. African. J. Biotechnol. 5(2):54-72.

Jayanti, J.F.L. 2002. Studi Kitinase dan Kitin Deasetilase Termostabil dari Isolat Asal Manado. Skripsi. Jurusan Teknologi Pangan dan Gizi, Fakultas Teknologi Pertanian, IPB, Bogor.

Katatny, M. H. E., Somitsch, W. Robra, K. H. Katatny, M. S. E., and Gubitz, G. M. 2000. Production of Chitinase and 1,3-glucanase by Trichoderma harzianum for Control of the Phytopathogenic Fungus Sclerotium rolfsii. J. Food. Technol. Biotechnol. 38(3):173-180.

Krisnawang, H., Fawzya, Y.N., and Noviendri, D. 2006. Optimasi dan Karakterisasi Parsial Enzim Kitosanase Dari Isolat KPU218 asal Limbah Udang. Dipresentasikan pada Seminar Nasional dan Diseminasi Teknologi Hasil Perikanan di Lampung. Tanggal 4-5 Desember 2006.

Lehninger, A.L. 1995. Dasar-dasar Biokimia. Jilid 1. Erlangga, Jakarta.

Lestari, P. 2000. Karakterisasi Kitinase Ekstraseluler Asal Bakteri Termofilik GP18 dari Sumber Air Panas Gunung Pancar. Thesis Pascasarjana, IPB.
Mahadevan, B. and Crawford, D.L. 1997. Properties of the chitinase of the antifungal biocontrol agent Streptomyces lydicus WYEC108. J. Enzyme Microb. Technol. 20: 489-493.

Martinou, A., Kafetzopoulos, D., and Bouriotis, V. 1995. Chitin deacetylation by enzymatic means: monitoring of deacetylation processes. J. Carbohidr. Res. 273(2): 235-242.

Noviendri, D., Chasanah, E., dan Fawzya, Y.N. 2006. Karakterisasi enzim kitinase yang diproduksi oleh isolat bakteri JB4 dari terasi. JPB. Perikanan. 1(2): 85-92.

Noviendri, D. dan Uria, A.R. 2008. Karakterisasi enzim kitinase 34Bs (Erwinia sp.) dari Lingkungan Laut Untuk Aplikasi Bioinsektisida. Temu IImiah Peneliti Badan Riset Kelautan dan Perikanan. DKP, Hotel Jayakarta, Jakarta. 12 pp.

Noviendri, D. dan Fawzya, Y.N. 2008. Produksi Enzim Kitosanase dari Bakteri Staphylococcus captis dan Pengaruh Perlakuan Ultrafiltrasi dan Liofilisasi Terhadap Aktivitasnya. Dipresentasikan pada Seminar Nasional Perikanan Indonesia 2008. Di Sekolah Tinggi Perikanan Jakarta. Pada tanggal 4-5 Desember 2008. 12 pp.

Oh, Y.S., Shih, I.L., Tzeng, Y.M., and Wang, S.L. 2000. Protease produced by Pseudomonas aeruginosa $\mathrm{K}-187$ and its application in deproteinization of shrimp and crab shell wastes. J. Enzyme. Microb. Technol. 27: 3-10.

Okazaki, K., Kawabata, T., Nakano, M., and Hayakawa, S. 1996. Purification and properties of chitinase from Arthrobacter sp. NHB-10. Biosci. Biotechnol. Biochem. 63(9): 1644-1646.

Park, S.H., Lee, J.H, and Lee, H.K. 2000. Purification and characterization of chitinase from a marine bacterium, Vibrio sp. 98CJ11027. J. Microbiol. 38(4): 224-229. 
Purwani, E.Y. 2002. Karakteristik Enzim Kitinase Termostabil dari Bakteri Termofilik Bacillus sp. 13.26. Thesis Program Pascasarjana, IPB.

Purwani, E.Y., Suhartono, M.T., Rukayadi, Y., Hwang, J.K., and Pyun, Y.R. 2004. Characteristics of thermostable chitinase enzymes from the Indonesian Bacillus sp. 13.26. J. Enzyme. Microbiol. Technol. 35: 147-153.

Rahayu, S. 2000. Pemurnian dan Karakterisasi Kitinase dan Kitin Deasetilase Termostabil dari Isolat Bacillus K-29-14 Asal Kawah Lamojang, Jawa Barat. Thesis Program Pascasarjana, IPB.

Rahayu, S., Tanuwidjaya, F., Rukayadi, Y., Suwanto, A., Suhartono, M. T., Hwang, J. K, and Pyun, Y.R. 2004. Study of Thermostable Chitinase Enzymes from Indonesian Bacillus K29-14. J. Microbiol. Biotechnol. 14(4): 647-652.

Situmorang, S.H. 2003. Karakterisasi Enzim Kitinase Termostabil Isolat Bacillus licheniformis MB-2 dari Tompaso, Sulawesi Utara Menggunakan Teknik Zimogram. Skripsi. Jurusan Teknologi Pangan dan Gizi, Fakultas Teknologi Pertanian, IPB, Bogor.

Splinder, K.D. 1997. Chitinase and chitosanase assays. In Muzzarelli, R.A.A. and Peter, M.G. (eds.). Chitin Handbook. Italy: Atec Grottammare. p. 229-235.

Suhartono, M.T. 1989. Enzim dan Bioteknologi. Depdikbud. Ditjen Dikti-PAU. IPB, Bogor. p. 53-102.

Tanaka, T., Fujiwara, S., Nishikori, S., Fukui, T., Takagi Masahiro, and Imanaka, T. 1999. A unique chitinase with dual active site and triple substrate binding sites from the hyperthermophilic archaeon Pyrococcus kodakaraensis KOD1. J. Applied. Environ. Microbiol. 65(12): 5338-5344.

Thatte, M.R. 2004. Synthesis and Antibacterial Assessment of Water-soluble Hydrophobic Chitosan Derivatives Bearing Quaternary Ammonium Functionality. PhD. Disertation. Lousiana State University, LA. 126 pp.

Thompson, S.E., Smith, M., Wilkinson, M.C, and Peek, K. 2001. Identification and Characterization of a Chitinase Antigen from Pseudomonas aeruginosa Strain 385. J. Applied. Environ. Microbiol. 67(9): 40014008.

Tokuyasu, K., Kaneko, S., Hayashi, K., and Mori, Y. 1999. Production of recombinant chitin deacetylation in the culture medium of Escherichia coli cells. J. FEBS. 458: 23-26.

Uria, A.R. and Chasanah, E. 2005. Chitinase and Chitosanase from Microorganism Associated with Marine Sponge. Dipresentasikan pada the $9^{\text {th }}$ of ASEAN Food Conference in Jakarta.

Wang, S.L. and Chang, W.T. 1997. Purification and characterization of two bifunctional chitinase/ lysozymes extracellularly produced by Pseudomonas aeruginosa $\mathrm{K}-187$ in a shrimp and crab shell powder medium. J. Applied. Environ. Microbiol. 63(2): 380-386.

Zilda, D.S. and Chasanah, E. 2005. Screening of Chitinolitic Bacteria from Terasi. Dipresentasikan pada the $9^{\text {th }}$ of ASEAN Food Conference di Jakarta. 